\title{
A GREVE E OS PERIÓDICOS CIENTÍFICOS
}

$\mathrm{E}$

ntre junho e setembro desse ano, aproximadamente, várias universidades federais do Brasil estiveram em greve. Foi esse o caso da Universidade Federal de Goiás. O movimento mobilizou alunos, professores e técnicos-administrativos. Basicamente, reivindicavam-se melhores condições de ensino, pesquisa e extensão, bem como melhorias nos salários e reestruturação da carreira docente.

Como não poderia deixar de ser, a paralisação de parte dos serviços da Universidade atinge seu funcionamento em vários aspectos. Os periódicos científicos não foram exceção. Inevitavelmente, o processo editorial envolve um conjunto relativamente complexo de processos administrativos, desde a contratação de empresas responsáveis pela revisão e normatização dos artigos, até o suporte dos sistemas operacionais de que se valem as revistas. Tudo isso fica em larga medida prejudicado em razão direta da greve. Somam-se a isso as necessidades permanentes de avaliações e pareceres, geralmente realizados por professores que, em muitos casos, encontravam-se em greve.

A discussão sobre até que ponto uma greve universitária deve paralisar as atividades propriamente científicas de um professor é assunto controverso e ainda não suficientemente discutido. Alguns acreditam que a greve interrompe fundamentalmente as atividades de ensino e administração, isentando as tarefas acadêmicas ligadas à pesquisa e divulgação científica. Outros, no entanto, creem que a greve deve dizer respeito a todas as atividades universitárias, excluindo-se apenas àquelas previstas em lei, como é o caso dos atendimentos hospitalares considerados serviços essenciais.

Em geral, greves em universidades federais têm historicamente afetado pouco as atividades de pesquisa. $\mathrm{O}$ funcionamento dos cursos de pós-graduação frequentemente não são paralisados por acontecimentos dessa natureza. Nessa última greve, porém, muitos professores, se não interromperam propriamente suas pesquisas, ao menos consideraram seriamente a possibilidade de fazê-lo, dada a complexidade política e estrutural desse momento institucional. A greve no quadro de servidores de órgãos de fomento, como a Capes e o CNPq, tornou ainda mais delicada a situação, mostrando que o trabalho cien- 
tífico também é trabalho e não está imune, portanto, a reivindicações trabalhistas.

Mesmo assim, o trabalho editorial dos periódicos científicos, até onde sabemos, seguiu, em tempo integral, como sempre: 24 horas por dia, 7 dias por semana, 365 dias por ano. A Revista Pensar a Prática recebe artigos para avaliação praticamente todos os dias, com ou sem greve, incluindo sábados, domingos e feriados santos, sem trégua.

Nesses dois contextos, de greve, por um lado, e demandas ininterruptas, por outro, nos esforçamos por manter funcionando o expediente da revista, dentro do possível. Tomamos esta decisão, especialmente considerando os possíveis efeitos e desdobramentos que uma paralisação por tempo indeterminado poderia causar, inclusive, colocando em risco o histórico de anos de trabalho que deram vida a este periódico. O possível, nesse caso, dizia respeito a publicação de mais este fascículo, os preparativos para publicação do próximo e a continuação dos procedimentos de avaliação, cujo tempo médio, de todo modo, sofreu ligeiro aumento, tanto por causa das dificuldades administrativas decorrentes da greve, quanto por causa das crônicas dificuldades de obtenção de pareces, que continuam também, com ou sem greve.

Cleber Dias Ana Márcia Silva

Editores 